\title{
Chemical studies on cypress leaves (Cupressus sempervirens) and their activity as antimicrobial agents
}

\author{
N. A. Azzaz, S. S. Hamed and T. A. Kenawy * \\ ${ }^{1}$ Agriculture Biochemistry Department, Faculty of Agriculture, Damietta University, Damietta, Egypt \\ * Corresponding author E-mail: Amknawy@gmail.com (T. Kenawy).
}

\section{ABSTRACT}

Cupressus sempervirens is an important medicinal plant in Egypt and the Eastern Mediterranean region. The aim of this work is to evaluate the chemical composition of cupressus leaves as medical plant. We used routine chemical analysis, chemical extractions (methanol and dichloromethane, steam distillation), and GC- mass methods to detect bioactive compounds. of cypress leaves. The results indicated that the percentage of fat was $9.55 \%$; moisture, $7.54 \%$; protein, 9.24\%; ash, $11.1 \%$; fiber, $7.4 \%$; and the percentage of carbohydrates was $55.17 \%$. Alkaloids, flavonoids, phenols, saponin, terbines, tannins groups were detected, while ricin group was absent. Moreover, eighteen components were identified and measured. Sabinene was the main ingredient (67.46\%), followed by 3-thujin (8.50\%), cetronella (5.04\%), 4 terpinol (5.01\%). Five essential oils were detected including citronella (5.04\%), followed by D-limonene $(2.94 \%), \alpha-$ citronellol (1.88\%), and terpinolene $(1.12 \%)$. In conclusion, pilot extracted oil of cypress leaves could be used to control microbial activity against some fungi species such as Verticillium and Aspergillus.

Keywords: Biological activities; Cupressus sempervirens; Medicinal plant.

\section{INTRODUCTION}

Cupressus sempervirens is one of traditional medicinal plants. It belongs to Cupressaceae family and it is a species of cypress native to the eastern Mediterranean region. The plant is known for its leaf oil "commercially known as cypress oil" which is used to protect stored grains from insect infestation (Elansary et al., 2012). Dried leaves are used in treatment of stomach pain, diabetes, inflammation, toothache, laryngitis and as contraceptive (Selim et al., 2014).

The genus Cupressus contains more than 20 species distributed in the Mediterranean region, tropical Asia, and North America, and five of these are endemic to China. (Chun-Mei et al., 2010).

The leaves of cupressus tree have a wide range of biological activities such as antioxidant, antidiabetic, reduce high blood pressure, anticancer and antimicrobial. The preliminary phytochemical analysis showed that the plant contained alkaloids $0.7 \%$, flavonoids $0.22 \%$, tannin $0.31 \%$, saponins $1.9 \%$, phenols $0.067 \%$, essential oils, and many other biologically active constituents. The previous pharmacological studies revealed that Cupressus sempervirens possesses antibacterial, antifungal, antiviral, antiparasitic, insecticidal, antioxidant, wound healing, anticancer, estrogenic, anticoagulant and many other effects (Al-Snafi, 2016). On the other hand, cypress contains a group of alkaloids $2-3 \%$, such as anabasine, a highly toxic volatile liquid, and other crystalline alkaloids such as aphylline, aphylidine, and lupine as concentrated in fruits. (Al-Snafi, 2016).
Traditionally the genus Cupressus is used in rheumatism, whooping cough and styptic problem (Kuiate et al., 2006). It eliminates fluid retention and is used to promote venous circulation to the kidney and bladder area, to improve bladder tone (Thukral et al., 2014).

Mycotoxins are known to be potent hepatocarcinogens in animals and humans. The presence and growth of fungi may cause spoilage and result in a reduction in quality and quantity of foods. Aspergillus sp. are the most common fungal species which are able to produce mycotoxins in food and feedstuffs (Rattanachaikunsopon and Phumkhachorn, 2010).

The aim of this work is to evaluate the chemical composition of Cupressus (cypress) leaves as medical plant. This study includes the extraction of active ingredients and analysis by GC-Mass and determine the biological activities of the important constituents i.e alkaloids, phenolics, flavonoids, volatile oils and its effect on microorganisms' activities.

\section{MATERIAL AND METHODES}

The present study was carried out using the leaves of Cupressus sempervirens, Family Cupressaceae to studying the chemical components of cupresses leaves.

\section{Preparation of samples}

Cupressus sempervirens leaves were collected from The Faculty of Agriculture farm, Al-Azhar University, Cairo, and the College of Computer and Information Sciences garden, Damietta University, in January and June 2017. A sample of the local market was purchased in Sohag in May. 
The leaves of cupressus were cleaned from dust and foreign materials, washed with tap water, then air dried in the shade at room temperature. The dried samples were ground using electric grinder into a fine powder and stored in plastic bags of self-locking polyethylene and preserved in a refrigerator until analysis.

\section{Extraction}

In the analysis of medicinal plants, extraction is the crucial first step because it is necessary to extract the desired chemical components from the plant materials for further separation and characterisation (Sasidharan et al., 2010). Different extraction techniques are available, but the most common ones used in plants extraction are the conventional techniques. In conventional extraction, the release of the desired compounds traditionally requires soaking and maceration in mild solvents (Chan et al., 2012).

\section{Solvation Extraction}

Mixture of Methanol (70\%): DCM (1:1), methanol, ethanol, ethyl acetate and chloroform are used in chemical extraction, phytochemical screening and microbiological Tests.

\section{Extraction of Cupressus $S$. leaves essential oil}

According to (Ozkan et al., 2010) 2 hundred grams of crushed leaves were taken; the essential oil was obtained by steam distillation in $1 \mathrm{~L} \mathrm{H}_{2} \mathrm{O}$ for 4 using local clevenger apparatus. The oil was dried over anhydrous sodium sulphate and filtered the oil was collected and measured. Cupressus s. leaves essential oil stored at $4{ }^{\circ} \mathrm{C}$ until use for analysis.

\section{Chemical analysis of cupressus leaves}

\section{Total Content of Cupressus Tree Leaves}

A quantitative estimation for the values of chemical composition for sample of cypress leaf powder was achieved at wavelength region from $\sim 750 \mathrm{~nm}$ to $2500 \mathrm{~nm}$ of the electromagnetic spectrum, using Near-InfraRed (NIR) Spectroscopy apparatus, model DA1650, which manufactured by FOSS Corporation. The estimation of the Chemical Composition was achieved at the central laboratory, Faculty of Agriculture, Al-Azhar University.

\section{Phytochemical screening}

Phytochemicals are chemicals derived from plants and the term is often used to describe the large number of secondary metabolic compounds found in plants. Phytochemical screening assay is a simple, quick, and inexpensive procedure that gives the researcher a quick answer to the various types of phytochemicals in a mixture and an important tool in bioactive compound analyses
(Sasidharan et al., 2010). The crude dichloromethane: methanol extract $(1: 1, \mathrm{v} / \mathrm{v})$ of cupressus s. and the methanolic extract of Sage were separately subjected to the following tests:

\section{Detection of terpenes}

Terpenes were detected according to the method described by Finar (1968). A small amount of crude extraction of sample was dissolved in chloroform, and then a few drops of concentrated sulfuric acid were carefully added on the wall of the test tube to form two separated layers, the resulted yellow ring changed to orange then red indicating the presence of terpenes.

\section{Detection of tannins}

Tannins were detected according to the method described by Gonzalez and Delgado, (1962). Few milliliters of distilled water were added to a small amount of crude Cupressus s. leaves extracted and filtrate, then one $\mathrm{mL}$ of ferric chloride solution $(5 \%)$ was added to the filtrate. A yellowish green color was developed in the presence of tannins.

\section{Detection of flavonoids}

Flavonoids were detected according to the method described by Geissman (1962). About 100 $\mathrm{mg}$ of crude cupressus leaves extract was dissolved in one $\mathrm{mL}$ of $90 \%$ methanol and spotted on a filter paper, left to dry then sprayed with $1 \%$ aluminum chloride solution. The appearance of yellow color indicated the presence of flavonoids.

\section{Detection of saponins}

Cupressus leaves sample was shacked with distilled water to obtain crude aqueous extract. A voluminous froth was developed with vigorously shaking which persisted for almost one hour indicated the presence of saponins.

\section{Detection of resins}

Resins were detected according to the method described by Trease (1961). About $200 \mathrm{mg}$ of crude extract was boiled on water bath for $20 \mathrm{~min}$. and distilled water was added to the extract, a white precipitate was formed refers to the presence of resins.

\section{Detection of alkaloids}

Alkaloids were detected according to Harborne (1988) by adding $2 \mathrm{~mL}$ of diluted hydrochloric acid to $1 \mathrm{~mL}$ of plant extract. Then five drops of Wagner's reagent were added with shaking to $1 \mathrm{~mL}$ of the previous solution. After few minutes, the formed precipitate indicating the presence of alkaloids. 


\section{GC-MS analysis for aromatic components in cupressus oil}

GC-MS analysis was carried out on a column DB1, 15M; 0.25mm ID (J\&W Scientific). The oven temperature program was the same as GC analysis and the mass spectrometer was operated in electron impact (EI) mode at 70ev ionization energy. The temperature program was set at $40{ }^{\circ} \mathrm{C}$ $(1 \mathrm{~min})-280{ }^{\circ} \mathrm{C}(3 \mathrm{~min})$ at $7.5^{\circ} \mathrm{C} / \mathrm{min}$. Detector and Injector temperature was set at $300{ }^{\circ} \mathrm{C}$ and $200{ }^{\circ} \mathrm{C}$, respectively. Helium was used as carrier gas flow at approximately $1.5 \mathrm{~mL} / \mathrm{min}$. Nist Wiley mass spectral database was used in the identification of the separated peaks.

\section{Antimicrobial Activity}

The standardized disc-agar diffusion method (Bauer-Kirby, 1966; CLSI, 2006) was followed to determine the antimicrobial activity of the cypress oil against the plant pathogenic fungi; Verticillium albo-atrum, Fusarium oxysporum f. sp. lycopersici and Aspergillus niger in addition to the plant tumorigenic, Agrobacterium tumefaciens. The tested oil was diluted in dimethyl formamide (DMF) to a concentration of $100 \mathrm{mg} / \mathrm{mL}$.

Inoculum of each tested fungus were prepared by transferring many loopfuls from the actively growing cultures to sterilized test tubes contains $10 \mathrm{~mL}$ of sterile distilled water. The test tube was agitated, and $0.5 \mathrm{~mL}$ of the suspension was swabbed uniformly on potato dextrose agar (PDA) medium using sterile cotton swab. The inoculum was allowed to dry for $5 \mathrm{~min}$ and uniform size filter paper disks (6 $\mathrm{mm}$ in diameter) were impregnated by $10 \mu \mathrm{L}$ from prepared oil concentration and carefully placed on surface of each inoculated plate. Three replicates were carried out for each tested organism and disks treated with DMF only were used as a control. The plates were incubated in the upright position at $30^{\circ} \mathrm{C}$ for 3 days and then checked for presence of growth inhibition zones formed around the disc.

In the case of Agrobacterium, the bacteria were grown in nutrient broth at $30{ }^{\circ} \mathrm{C}$ for 2 days and adjusted to a concentration of $10^{8} \mathrm{CFU} / \mathrm{mL}$ in sterile distilled water then the same procedure was followed as described above to perform the test.

To evaluate the effect of cypress leaves on microbial activity two types of leaves extracts were used: ethanol extract, mixture of methanol and dichloroethane extract as well as the volatile oil extracted from the leaves and incubated at 28 ${ }^{\circ} \mathrm{C}$ for two weeks.

\section{Determination of sample cytotoxicity on cells (MTT protocol)}

The 96 well tissue culture plate was inoculated with 1 X $10{ }^{5}$ cells / mL (100 $\mu \mathrm{L} /$ well) and incubated at $37^{\circ} \mathrm{C}$ for $24 \mathrm{~h}$ to develop a complete monolayer sheet.

Growth medium was decanted from 96 well micro titer plates after confluent sheet of cells were formed, cell monolayer was washed twice with wash media.

Two-fold dilutions of tested sample were made in RPMI medium with $2 \%$ serum (maintenance medium). $0.1 \mathrm{~mL}$ of each dilution was tested in different wells leaving 3 wells as control, receiving only maintenance medium.

Plate was incubated at $37^{\circ} \mathrm{C}$ and examined. Cells were checked for any physical signs of toxicity, e.g. partial or complete loss of the monolayer, rounding, shrinkage, or cell granulation.

MTT solution was prepared $(5 \mathrm{mg} / \mathrm{mL}$ in PBS)

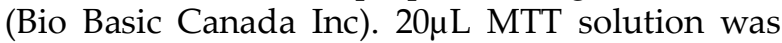
added to each well. Place on a shaking table, 150rpm for $5 \mathrm{~min}$, to thoroughly mix the MTT into the media.

The samples were incubated $\left(37^{\circ} \mathrm{C}, 5 \% \mathrm{CO}_{2}\right)$ for 1-5 $\mathrm{h}$ to allow the MTT to be metabolized, and then the media was dumped off. We dried the plate on paper towels to remove residue if necessary.

We resuspended formazan (MTT metabolic product) in $200 \mu \mathrm{L}$ DMSO and placed on a shaking table, $150 \mathrm{rpm}$ for $5 \mathrm{~min}$, to thoroughly mix the formazan into the solvent.

The optical density was 560nm and background was subtracted at $620 \mathrm{~nm}$. Optical density was directly correlated with cell quantity (Slater, et al., 1963; van de Loosdrecht et al., 1994; Alley, et al., 1988).

\section{RESULTS AND DISCUSSION}

The present study was carried out on one of medicinal plants Cupressus sempervirens. The study included the chemical analysis of plant cupressus leaves, chemical components of volatile oil, estimation of active components in cupressus leaves such as total polyphenols, total flavonoids, essential oil and alkaloids were also done. And antimicrobial activities were studied as follow:

\section{Chemical analysis of cupressus leaves}

The percentage of fat was $9.55 \%$; moisture, $7.54 \%$; protein, $9.24 \%$; ash, $11.1 \%$; fiber, $7.4 \%$; and the percentage of carbohydrates was $55.17 \%$ as shown in Table (1). 


\section{Preparatory phytochemical screening of cupressus leaves extract}

Methanolic extract (ME), ethanolic extract (EE), chloroform extract (CHE) and aqueous extract (AE) of the plant sample were subjected to phytochemical screening. Results showed that cupressus methanolic extract contained tannins, and alkaloids except terpenes, saponins, flavonoids and resins. Chloroform extract contained terpenes and alkaloids except tannins, flavonoids, saponins and resins. While, ethanolic extract contained tannins, flavonoids, and alkaloids except terpenes, saponins, and resins. The aqueous extract of cypress leaves showed the presence of saponins. as shown in Table (2).

\section{Chemical composition of cupressus leaves using GC-MS}

The chemical composition of essential oil of Cypress Leaves was determined using GC-MS. The identification of the volatile components was carried out by comparing their mass spectra and retention times with those of reference standards. From results recorded in Table 3, eighteen components were identified and measured. Sabinene was the main component (67.46\%) followed by 3-thujene (8.50\%), citronella (5.04\%), 4-terpineol $(5.01 \%), \quad c ̧$-Terpinene $(3.35 \%), \quad$ Dlimonene $(2.94 \%), \quad \alpha$-terpinene $(2.33 \%), \alpha$ citronellol $(1.88 \%), \alpha$-terpinolene $(1.12 \%)$. The lowest ratios were N-Acetyl-1-hydroxybutan-2ylamide $(0.92 \%)$, camphene $(0.57 \%)$, linalool $(0.36 \%)$, Bis (2-ethylhexyl) phthalate (0.20\%), diisooctyl phthalate $(0.09 \%)$.

\section{Antimicrobial Activities}

Cypress oil has a strong pungent odor and contains some terpenes that are characterized by their anti-fungal and bacterial properties, making them particularly interesting in the field of control of plant pathogens and the establishment of fungicides. The inhibitory effect of cypress oil on some fungal pathogenic microorganisms as Verticillium, Fusarium oxysporum Aspergillus and bacterial pathogenic Agrobacterium have been studied, since the test was conducted from two different concentrations (75 and $100 \mathrm{ppm}$ ), to study the inhibitory ability of cypress oil for some fungal and bacterial pathogenic of the plant.

The results in Table (4) showed that there was no inhibiting effect on growth when pathogenic microbes treated with mixture of methanol (70\%) extract and dichloromethane (1: 1) and ethanolic extract (at the concentration of 75ppm), during the experiment, but when such microbes treated with volatile oil extracted from the cypress leaves, there was an inhibiting effect on growth through (4-6) days for both vertsillium and Fuzarium. Then the inhibiting effect begun gradually to decrease after 6-8 days of incubation period. The fungi of the latter species were able to grow and overcome the effect of the substance, while in the case of Aspergillus there was no discouragement, as shown in Plate (1). All results were negative in the case of bacteria. At the concentration of 100 ppm, there was no significant effect on the studied microorganisms from the used extracts during the two-week period. While in the case of volatile oil, Aspergillus increased the area of $13 \mathrm{~mm}$ during the first week. This effect continued during the second week in a contrast zone of $13 \mathrm{~mm}$, indicating the stability of the effect of volatile cypress oil against fungi and the inability of fungi to grow. While in the concentration of $75 \%$ there was no effect of cypress oil on the same fungus. As for fuzarium, there was a slight effect of cypress oil (75\% concentration) at the beginning of the first week by inhibition zone $7 \mathrm{~mm}$ disappeared after the fourth day under the fungal germs, while in the $100 \%$ concentration there was no inhibition during the test period. As for fungus vertsillium, the concentration of $100 \%$ of cypress oil had an antifungal effect, since the inhibition zone was 9 $\mathrm{mm}$ during the first week of incubation and gradually began to shrink from the second week until it disappeared at the end of the incubation period. At the concentration of cypress oil was $75 \%$, at the beginning of the first week of $8 \mathrm{~mm}$ the antifungal effect disappeared gradually under the growth of fungi at the end of the first week of incubation. In case of bacteria, there was no effect during the duration of the test.

\section{Antitumor Activities}

\section{Functional assay of effect against Caco2 cells}

Table (5) shows that the effect of 6 different concentrations of cypress oil and methanolic extract of cypress plant on cellular toxicity on cells. The toxicity \% was increased and the most effective concentration of the tested samples was detected at $10000 \mu \mathrm{g} / \mathrm{mL}$ against Caco2 cell lines. The methanolic extracts of cupressus plant had the highest toxic effect, while cupressus oil had the lowest toxicity as Shown in Figures $(3,4)$. LC 50 (which represents the effect on $50 \%$ of the tested cells) was detected at the lowest value (1240 $\mu \mathrm{g} / \mathrm{mL}$ ) in case of cypress extract and $\mathrm{LC}_{50}$ $(11995.7 \mu \mathrm{g} / \mathrm{mL})$ in case of oil form.

\section{CONCLUSION}

It can be concluded that cypress oil had an antifungal effect of Aspergillus and vertsillium at a concentration of $100 \%$ and more effective on Aspergillus as it showed stability throughout the test period. The chemical composition of cypress oil reveals the importance of its oily form to exhibit antifungal properties. 


\section{REFERANCES}

Alley, M.C., Scudiero, D.A., Monks, A., Hursey, M.L., Czerwinski, M.J., Fine, D.L., Boyd, M.R., 1988. Feasibility of drug screening with panels of human tumor cell lines using a microculture tetrazolium assay. Cancer Res., 48 (3), 589-601.

Al-Snafi, A.E., 2016. Medical importance of Cupressus sempervirens-A review. IOSR J. Pharm., 6 (6), 66-76.

Bauer, A.W., 1966. Antibiotic susceptibility testing by a standardized single disc method. Am. J. Clin. Pathol., 45, 149-158.

Chan, C., Ngoh, G., Yusoff, R., 2012. A brief review on anti-diabetic plants: global distribution, active ingredients, extraction techniques and acting mechanisms. Pharmacogn. Rev., 6 (11), 22-28.

Liu, C.M., Zhou, H.B., Zhang, W.D., 2010. Terpenoids from stems and leaves of Cupressus gigantea. Chin. J. Nat. Medicines, 8 (6), 405-410.

Clinical and Laboratory Standards Institute, 2006. Performance standards for antimicrobial susceptibility testing, 16th informational supplement M100-S16. Wayne.

CLSI (NCCLS), 2003. Methods for dilution antimicrobial susceptibility tests for bacteria that grow aerobically; approved standard M7A6. 6th Ed. National Committee for Clinical Laboratory Standards.Wayne, Pa, USA:

Elansary, H.O., Salem, M.Z., Ashmawy, N.A., Yacout, M.M., 2012. Chemical composition, antibacterial and antioxidant activities of leaves essential oils from Syzygium cumini L., Cupressus sempervirens L. and Lantana camara L. from Egypt. J. Agric. Sci., 4 (10), 144-152.

Finar, O.P., Yang, M., Wen, H., Chern, J., 1968 Estimation of total flavonoid content in plant extract by two complementary colorimetric methods. J. Food Drug Anal., 10, 178-182.

Geissman, K.E., Tagliaferro, A.R., Bobilya, D.J., 1962. Flavonoid antioxidants: chemistry, metabolism and structure-activity relationships. J. Nutr. Biochem., 13, 572-584.

Gonzalez, L.O., Delgado, T.R., 1962. Polyphenols and phytochemical screening, chemistry, dietary sources, metabolism, and nutritional significance. Nutr. Rev., 56, 317-333.

Harborne, J.B., 1988. Phytochemical Methods: A Guide to Modern Techniques of Plant
Analysis. (3rd Ed.). Chapman and Hall Co., New York, pp. 1-302.

Kuiate, J.R., Bessiere, J.M., Zollo, P.H.A., Kuate, S.P., 2006. Chemical composition and antidermatophytic properties of volatile fractions of hexanic extract from leaves of Cupressus lusitanica Mill. from Cameroon. J. Ethnopharmacol., 103 (2), 160-165.

Ozkan, G., Sagdic, O., Gokturk, R.S., Unal, O., Albayrak, S., 2010. Study on chemical composition and biological activities of essential oil of Cymbopon citratus LWT-Food Sci Technol., 43 (1),186-190.

Rattanachaikunsopon, P., Phumkhachorn, P., 2010. Contents and antibacterial activity of flavonoids extracted from leaves of Psidium guajava. J. Med. Plants Res., 4 (5), 393-396.

Sasidhara, S., Chen, Y., Saravanan, D., Sundram K.M., Yoga Latha L., 2010. Extraction, isolation and characterization of bioactive compounds from plants' extracts. Afr. J. Tradit. Complement. Altern. Med.,8 (1), 1-10

Selim, S.A., Adam, M.E., Hassan, S.M., Albalawi, A.R., 2014. Chemical composition, antimicrobial and antibiofilm activity of the essential oil and methanol extract of the Mediterranean cypress (Cupressus sempervirens L.). BMC complemen. Altern. Med., 14 (1), 179.

Slater, T.F., Sawyer, B., Sträuli, U. 1963. Studies on succinate-tetrazolium reductase systems: III. Points of coupling of four different tetrazolium salts III. Points of coupling of four different tetrazolium salts. Biochim. Biophys. Acta, 77, 383-393.

Thukral, S.K., Singh, S., Sharma, S.K., 2014. Pharmacognostical standardization of leaves of Cupressus macrocarpa Hartweg. ex Gordon. J. Appl. Pharmaceut. Sci., 4 (5), 71-74.

Trease, V.B., 1961. Phytochemical Methods: A Guide to Modern Techniques of Plant Analysis. 3rd Ed., Chapman and Hall Co., NY, 1-302.

Van de Loosdrecht, A.A., Beelen, R.H.J., Ossenkoppele, G., Broekhoven, M.G., Langenhuijsen, M.M.A.C., 1994. A tetrazoliumbased colorimetric MTT assay to quantitate human monocyte mediated cytotoxicity against leukemic cells from cell lines and patients with acute myeloid leukemia. J. Immunol. Methods 174 (1-2), 311-32. 
Table 1. Total content of cupressus leaves.

\begin{tabular}{lcccccc}
\hline \multirow{2}{*}{$\begin{array}{l}\text { Component } \\
\text { PLANT }\end{array}$} & Fat & Moisture & protein & Ash & Fiber & $\begin{array}{c}\text { Total } \\
\text { carbohydrate }\end{array}$ \\
\hline $\begin{array}{l}\text { Cupressus } \\
\text { Leaves }\end{array}$ & 9.55 & 7.54 & 9.24 & 11.10 & 7.40 & 55.17 \\
\hline
\end{tabular}

Table 2. Preparatory phytochemical screening of crud extract.

\begin{tabular}{lcccc}
\hline \multirow{2}{*}{$\begin{array}{r}\text { Extract } \\
\text { Component }\end{array}$} & $\begin{array}{c}\text { Methanolic ex. } \\
\text { (ME) }\end{array}$ & $\begin{array}{c}\text { Chloroform ex. } \\
\text { (CHE) }\end{array}$ & $\begin{array}{c}\text { Ethanolic ex. } \\
\text { (EE) }\end{array}$ & $\begin{array}{c}\text { Aqueous-ex. } \\
\text { (AE) }\end{array}$ \\
\cline { 2 - 5 } Terpenes & - & ++ & - & $/ /$ \\
Tannins & + & - & + & $/ /$ \\
Flavonoids & - & $-/$ & $+/$ & $/ /$ \\
Saponins & - & - & - & $/ /$ \\
Resins & - & ++ & ++ & $/ /$ \\
Alkaloids & + & & + & + \\
\hline
\end{tabular}

$(++)$ strong $(+)$ medium $(-)$ absence $(/ /)$ not testing.

Table 3. Chemical composition of cupressus leaves oil using GC-MS.

\begin{tabular}{llc}
\hline RT & Compound Name & Area \% \\
\hline 9.64 & N-Acetyl-1-hydroxybutan-2-ylamide & 0.31 \\
9.70 & N-Acetyl-1-hydroxybutan-2-ylamide & 0.61 \\
21.64 & 3-Thujene & 8.50 \\
22.64 & Camphene & 0.57 \\
23.45 & Sabinene & 67.46 \\
24.96 & $\alpha$-Terpinene & 2.33 \\
25.36 & D-Limonene & 2.94 \\
26.30 & ç-Terpinene & 3.35 \\
27.22 & d-TERPINOLENE & 1.12 \\
27.91 & Linalool & 0.36 \\
29.43 & CITRONELLA & 5.04 \\
30.66 & 4-Terpineol & 5.01 \\
31.81 & á-Citronellol & 1.88 \\
47.57 & Bis(2-ethylhexyl) phthalate & 0.20 \\
47.62 & Diisooctyl phthalate & 0.09 \\
47.79 & 2,6-dimethyl-N-(2-methyl-à-phenylbenzyl)aniline & 0.09 \\
47.86 & Bis(2-ethylhexyl) phthalate & 0.07 \\
47.96 & 2,6-dimethyl-N-(2-methyl-à-phenylbenzyl)aniline & 0.06 \\
\hline
\end{tabular}


Table 4. Inhibition zone ( $\mathrm{mm}$ ) of fungal and bacterial growth as result of treatment by cupressus leaves extracts and volatile oil.

\begin{tabular}{|c|c|c|c|c|c|c|c|c|c|c|c|c|c|}
\hline \multirow[t]{3}{*}{$\begin{array}{l}\text { Tested Microbe } \\
\text { strains }\end{array}$} & \multirow[t]{3}{*}{$\begin{array}{l}\text { concen. } \\
\text { (ppm) }\end{array}$} & \multicolumn{4}{|c|}{$\begin{array}{c}\text { Ethanolic } \\
\text { extract }\end{array}$} & \multicolumn{4}{|c|}{$\begin{array}{c}\text { DCM: Methanolic } \\
\text { (1:1) v/v } \\
\text { extract }\end{array}$} & \multicolumn{4}{|c|}{ Volatile oil } \\
\hline & & \multicolumn{2}{|c|}{$\begin{array}{l}\text { First } \\
\text { week }\end{array}$} & \multicolumn{2}{|c|}{$\begin{array}{l}\text { Second } \\
\text { week }\end{array}$} & \multicolumn{2}{|c|}{$\begin{array}{c}\text { First } \\
\text { week }\end{array}$} & \multicolumn{2}{|c|}{$\begin{array}{c}\text { Second } \\
\text { week }\end{array}$} & \multicolumn{2}{|c|}{$\begin{array}{c}\text { First } \\
\text { week }\end{array}$} & \multicolumn{2}{|c|}{$\begin{array}{l}\text { Second } \\
\text { week }\end{array}$} \\
\hline & & $\begin{array}{l}3-4 \\
\text { day }\end{array}$ & $\begin{array}{l}5-7 \\
\text { day }\end{array}$ & $\begin{array}{l}8- \\
10 \\
\text { day }\end{array}$ & $\begin{array}{c}11-14 \\
\text { day }\end{array}$ & $\begin{array}{l}3-4 \\
\text { day }\end{array}$ & $\begin{array}{l}5-7 \\
\text { day }\end{array}$ & $\begin{array}{c}8- \\
10 \\
\text { day }\end{array}$ & $\begin{array}{l}11- \\
14 \\
\text { day }\end{array}$ & $\begin{array}{c}3- \\
4 \\
\text { da } \\
\text { y }\end{array}$ & $\begin{array}{c}5-7 \\
\text { da } \\
y\end{array}$ & $\begin{array}{l}8-10 \\
\text { day }\end{array}$ & $\begin{array}{l}11- \\
14 \\
\text { day }\end{array}$ \\
\hline \multirow[t]{2}{*}{ Aspergillus } & 100 & - & - & - & - & - & - & - & - & 13 & 13 & 13 & 13 \\
\hline & 75 & - & - & - & - & - & - & - & - & - & - & - & - \\
\hline \multirow[t]{2}{*}{ Fusarium } & 100 & - & - & - & - & - & - & - & - & - & - & - & - \\
\hline & 75 & - & - & - & - & - & - & - & - & 7 & - & - & - \\
\hline \multirow[t]{2}{*}{ Verticillium } & 100 & - & - & - & - & - & - & - & - & 9 & 9 & $8-7$ & - \\
\hline & 75 & - & - & - & - & - & - & - & - & 8 & - & - & - \\
\hline \multirow[t]{2}{*}{ Agrobacterium } & 100 & - & - & - & - & - & - & - & - & - & - & - & - \\
\hline & 75 & - & - & - & - & - & - & - & - & - & - & - & - \\
\hline
\end{tabular}

Table 5. Determination of sample cytotoxicity on cells (MTT protocol).

\begin{tabular}{|c|c|c|c|c|c|c|c|c|c|}
\hline ID & $\begin{array}{l}\text { Conc. } \\
\mu \mathrm{g} / \mathrm{mL}\end{array}$ & & O.D & & $\begin{array}{l}\text { Mean } \\
\text { O.D }\end{array}$ & ST.E & Viability \% & Toxicity \% & IC50 \\
\hline Caco2 & $1: 2$ & 0.253 & 0.274 & 0.262 & 0.263 & 0.006083 & 100 & 0 & $\mu \mathrm{g} / \mathrm{mL}$ \\
\hline \multirow{6}{*}{$\begin{array}{c}\text { Oil } \\
\text { extract }\end{array}$} & 10000 & 0.162 & 0.184 & 0.159 & 0.168333 & 0.007881 & 64.00506971 & 35.99493029 & \multirow{6}{*}{11995.7} \\
\hline & 5000 & 0.254 & 0.269 & 0.258 & 0.260333 & 0.004485 & 98.9860583 & 1.013941698 & \\
\hline & 2500 & 0.261 & 0.257 & 0.263 & 0.260333 & 0.001764 & 98.9860583 & 1.013941698 & \\
\hline & 1250 & 0.264 & 0.255 & 0.269 & 0.262667 & 0.004096 & 99.87325729 & 0.126742712 & \\
\hline & 625 & 0.264 & 0.253 & 0.27 & 0.262333 & 0.004978 & 99.74651458 & 0.253485425 & \\
\hline & 312.5 & 0.259 & 0.267 & 0.26 & 0.262 & 0.002517 & 99.61977186 & 0.380228137 & \\
\hline \multirow{8}{*}{ Extract } & 10000 & 0.035 & 0.028 & 0.033 & 0.032 & 0.002082 & 12.16730038 & 87.83269962 & \multirow{8}{*}{1240} \\
\hline & 5000 & 0.064 & 0.058 & 0.069 & 0.063667 & 0.00318 & 24.20785805 & 75.79214195 & \\
\hline & 2500 & 0.094 & 0.106 & 0.083 & 0.094333 & 0.006642 & 35.86818758 & 64.13181242 & \\
\hline & 1250 & 0.122 & 0.132 & 0.128 & 0.127333 & 0.002906 & 48.4157161 & 51.5842839 & \\
\hline & 625 & 0.203 & 0.199 & 0.216 & 0.206 & 0.005132 & 78.3269962 & 21.6730038 & \\
\hline & 312.5 & 0.246 & 0.266 & 0.262 & 0.258 & 0.00611 & 98.09885932 & 1.901140684 & \\
\hline & 156.25 & 0.258 & 0.263 & 0.261 & 0.260667 & 0.001453 & 99.11280101 & 0.887198986 & \\
\hline & 78.125 & 0.264 & 0.262 & 0.261 & 0.262333 & 0.000882 & 99.74651458 & 0.253485425 & \\
\hline
\end{tabular}

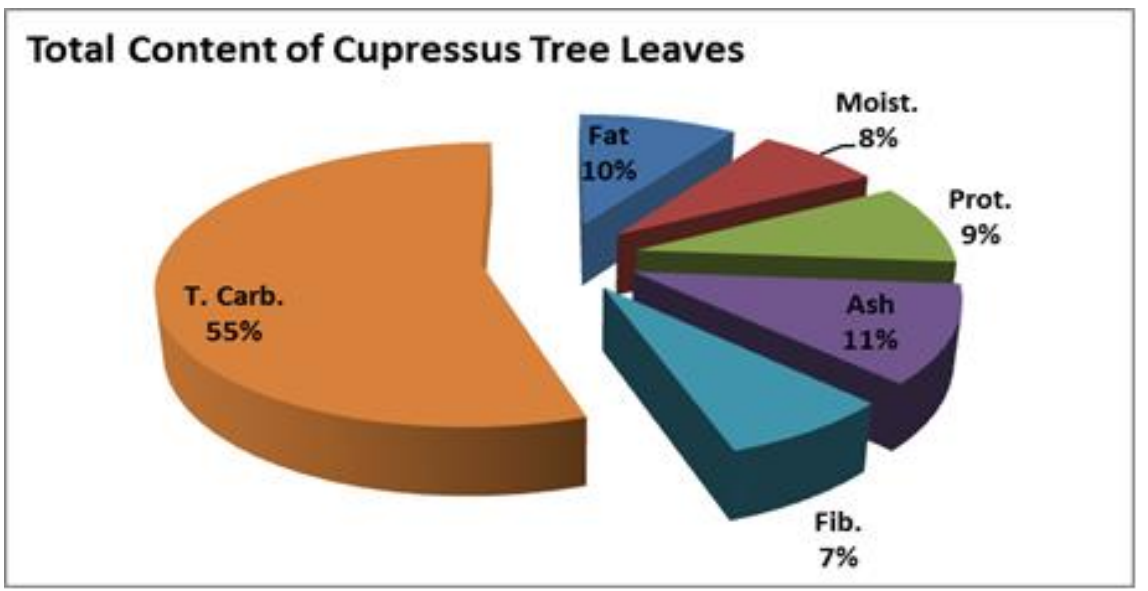

Figure 1. Total content of cupressus leaves. 


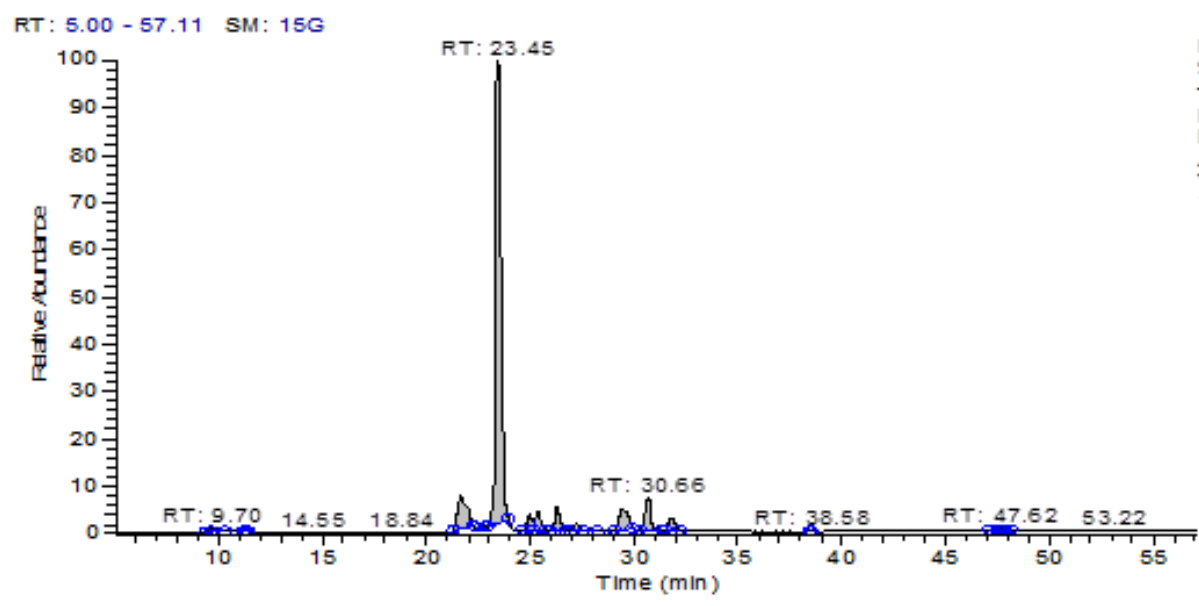

Figure 2. Chemical composition of cupressus leaves using GC-MS.

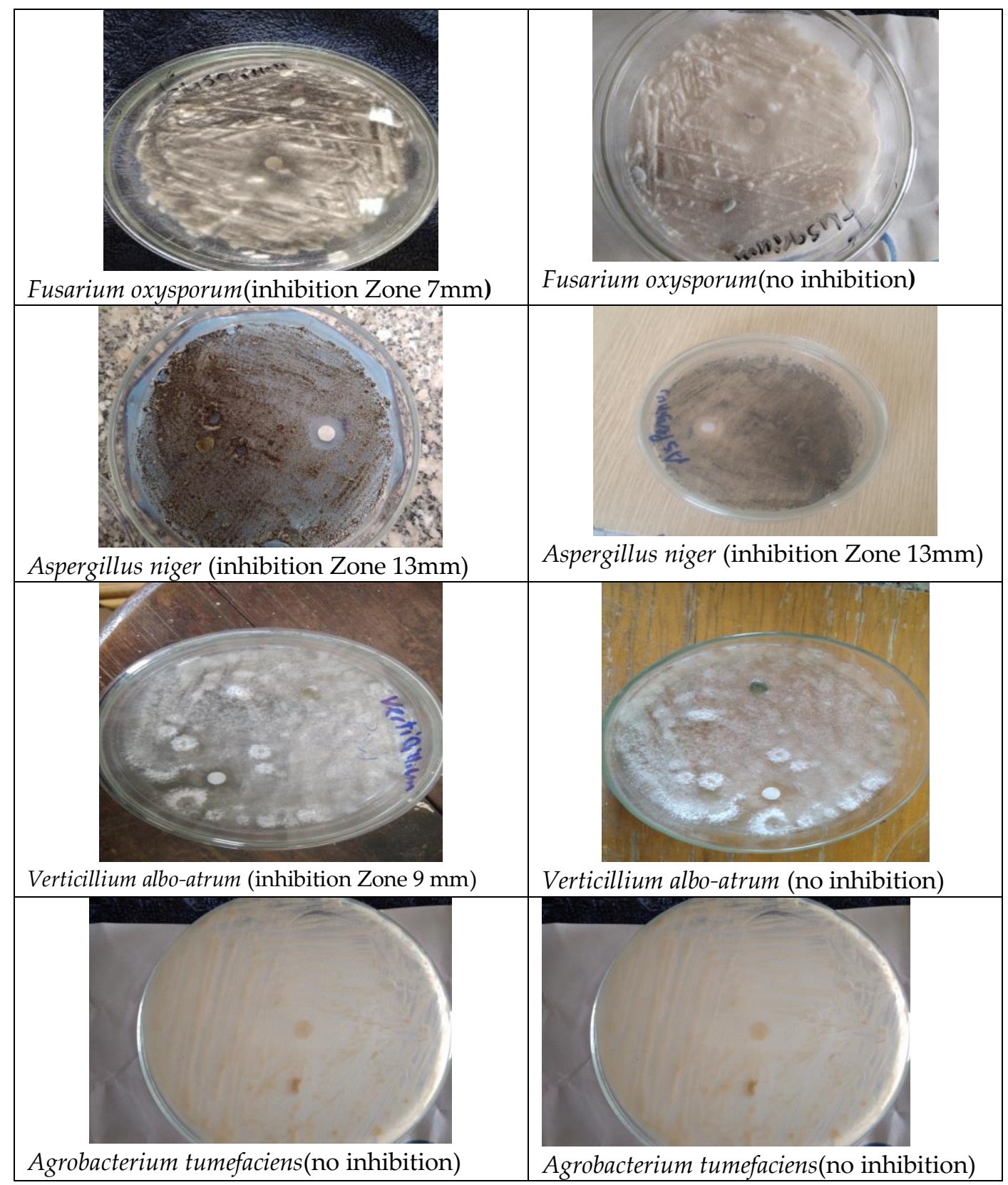

Plate1. Inhibition zone of fungal and bacterial grows. 


\section{Effect of oil on Caco-2 cells at different concentration}
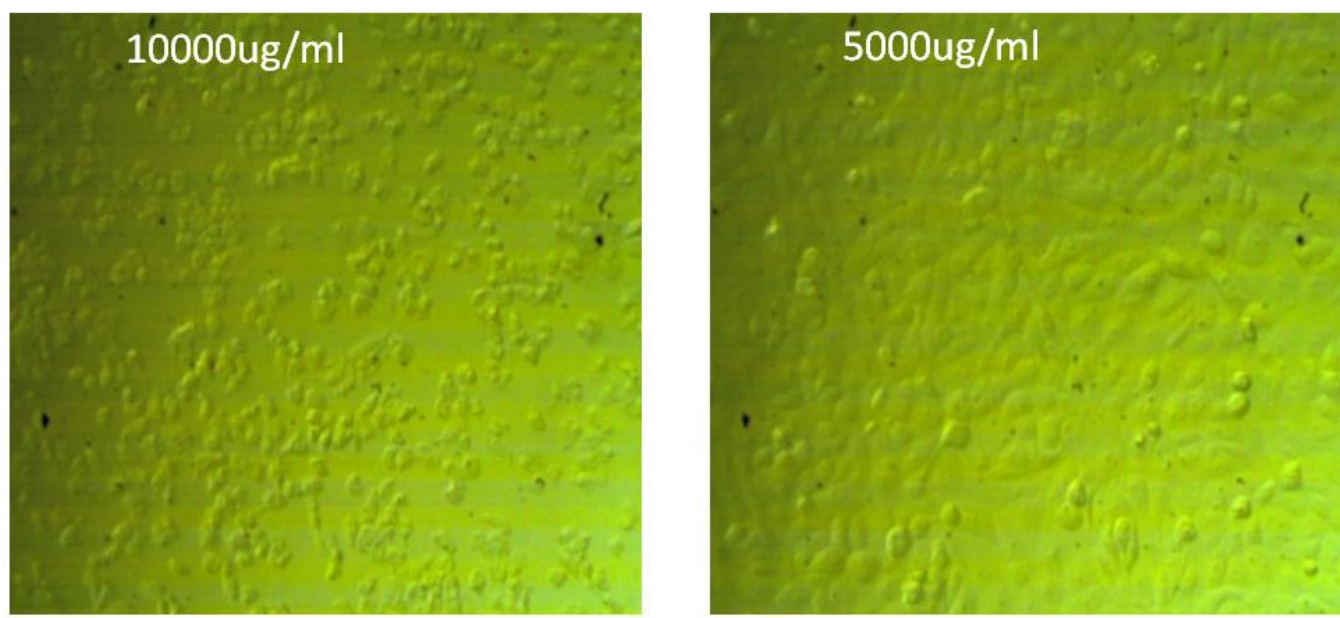

Figure 3. Effect of cupressus oil on Caco2 cells at different concentrations.

\section{Effect of extract on Caco-2 cells at different concentration}
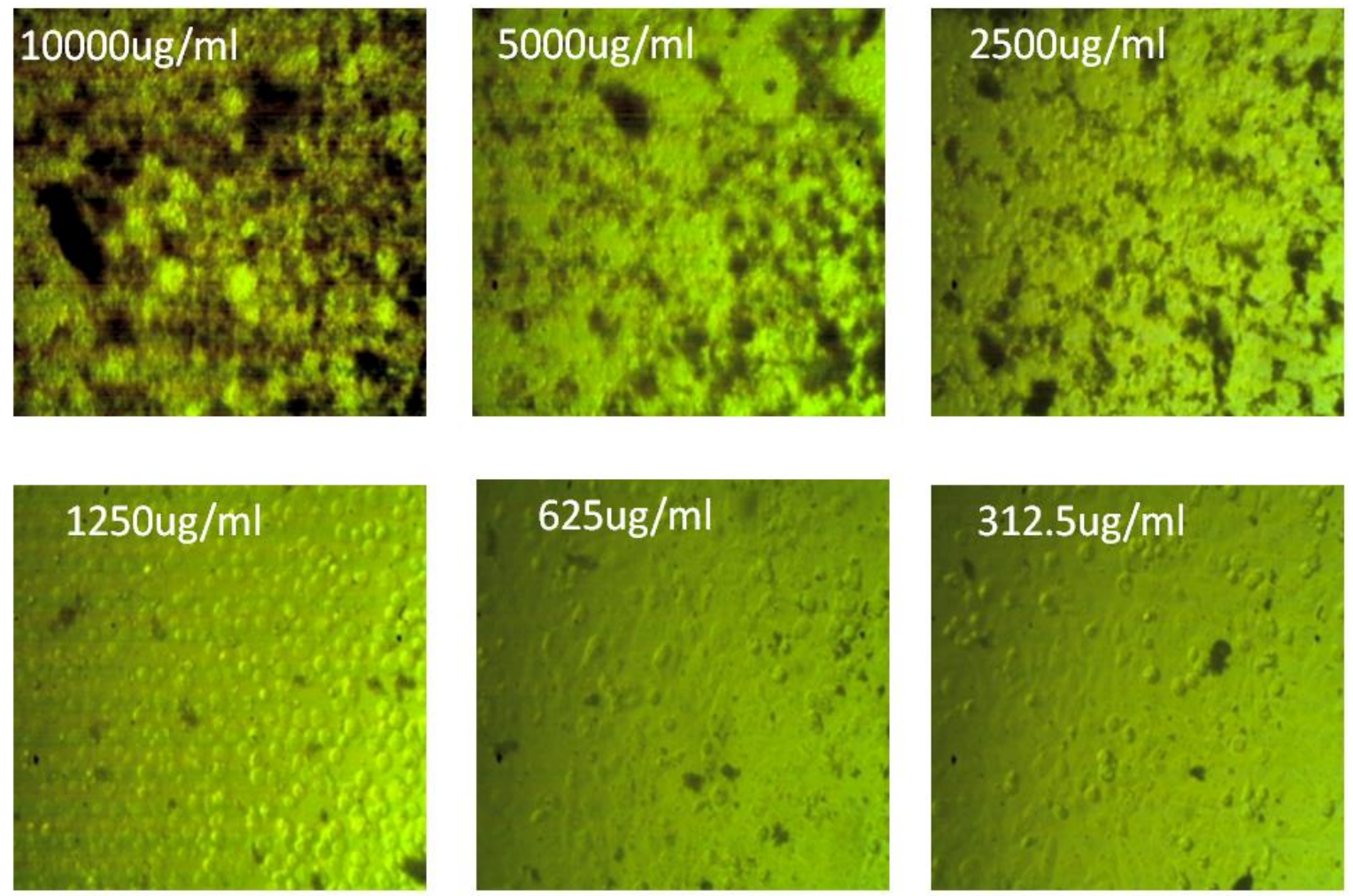

Figure 4. Effect of extract on $\mathrm{Caco} 2$ cells at different concentrations. 


\section{دراسات كميائية على أوراق السرو اللموني ونشاطها كضادات للميكروبات}

\section{نييل عبد المالق عزاز، سيحر حامد "، طلعت أحمد محمد قناوي}

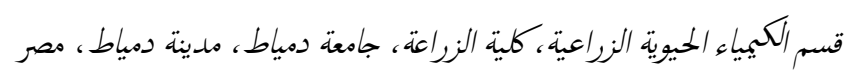

Amknawy@gmail.com البريد الإيكتروني للباحث الرئيسي:

الملخص العربي

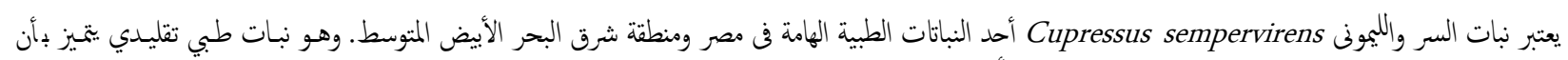

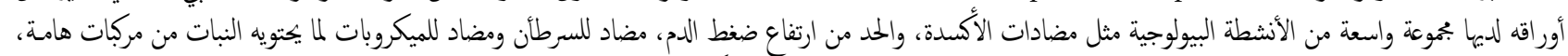

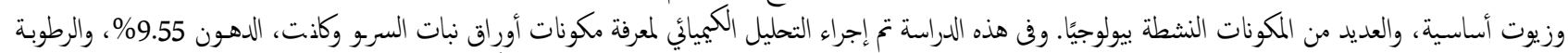

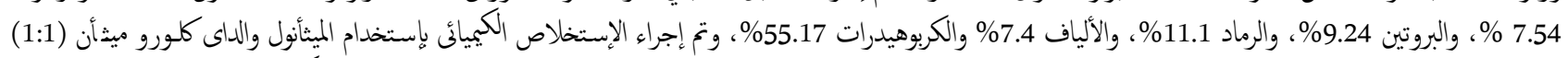

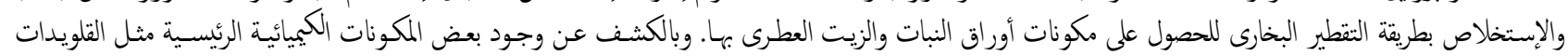

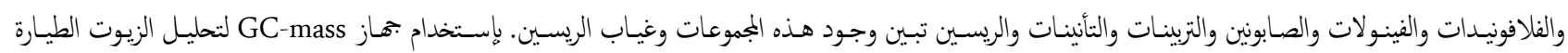

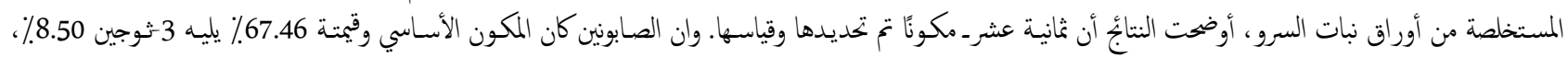

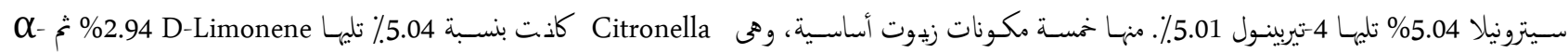

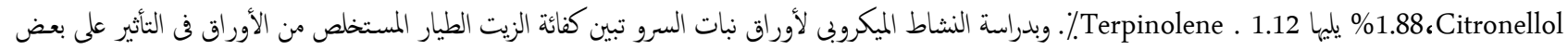

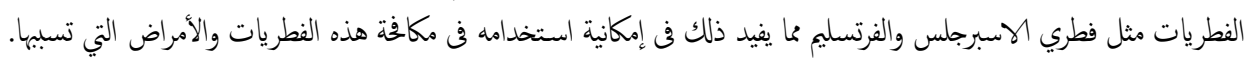
الكلات المفتاحية: الأنشطة البيولوجية، السر والميمونى، النباتات الطبية. 